\title{
LISTY MARCINA SZYSZKOWSKIEGO DO TOMASZA ZAMOYSKIEGO - ŹRÓDŁA DO SPRAW KOZACKICH I TATARSKO-TURECKICH (1623-1626)
}

Pierwsza połowa lat 20. XVII w. upłynęła w Rzeczypospolitej w znacznym stopniu pod znakiem spraw kozackich i tatarsko-tureckich. Świeżo zawarty pokój z Turcją był jeszcze nietrwały, a działalność Kozaków mogła łatwo doprowadzić do nowej wojny. Elity polityczne kraju, podobnie jak ,szeregowa” szlachta, były żywo zainteresowane w uspokojeniu granicy południowo-wschodniej. Uspokojenie to obejmowało zarówno znalezienie nowego modus vivendi z Kozakami, rozzuchwalonymi po swym udziale w obronie Chocimia w 1621 r., jak i utrwalenie pokoju z Osmanami. Sprawy te znalazły swoje miejsce w korespondencji czołowych przedstawicieli życia publicznego w ówczesnej Rzeczypospolitej. Zaliczyć do nich wypada m.in. biskupa krakowskiego, Marcina Szyszkowskiego - swego czasu aktywnego uczestnika gry politycznej, prowadzonej przez króla Zygmunta III Wazę - oraz ówczesnego wojewodę kijowskiego, Tomasza Zamoyskiego, któremu dopiero wróżono wielką karierę. W niniejszym artykule zaprezentujemy trzy listy, wysłane przez Marcina Szyszkowskiego do Tomasza Zamoyskiego w latach 1623-1626. Ich edycję poprzedzimy omówieniem sytuacji politycznej, która jest $\mathrm{w}$ głównej mierze przedmiotem tych listów, a także nakreślimy sylwetki polityczne obu korespondentów. Pozwoli to nie tylko zrozumieć treści, poruszane w listach, ale również ocenić ich przydatność dla studiów nad dziejami stosunków polsko-kozackich i polsko-turecko-tatarskich. Nie mniej ważne jest również rozpoznanie postaw elit państwa, w tym zwłaszcza duchownych, których przedstawicielem był Marcin Szyszkowski, wobec zagadnień polityki międzynarodowej i bezpieczeństwa kresów południowo-wschodnich w omawianym okresie. W tym zakresie prezentowane studium jest oczywiście tylko wstępem do szerzej zakrojonych badań, dotyczących udziału przedstawicieli Kościoła w życiu politycznym Rzeczypospolitej pierwszej połowy XVII w.

\footnotetext{
* Dariusz Milewski - dr historii, adiunkt w Katedrze Historii Nowożytnej Instytutu Nauk Historycznych UKSW w Warszawie.
} 
Wojna pomiędzy Rzecząpospolitą Obojga Narodów a Turcją Osmańską, do jakiej doszło w latach 1620-1621 po wielu dziesięcioleciach pokojowych stosunków - zakłócanych co prawda różnymi incydentami, które nie prowadziły jednak do otwartego konfliktu - była przede wszystkim skutkiem najazdów tatarskich na Ukrainę oraz wypraw Kozaków Zaporoskich na Morze Czarne. Obustronne grabieże musiały wreszcie przelać przysłowiową czarę goryczy. Nie bez skutków były też polskie działania, wymierzone w sojusznika Porty Ottomańskiej - księcia siedmiogrodzkiego Gabora Bethlena. Dążył on do zjednoczenia ziem węgierskich pod swoim panowaniem i był tym samym wrogiem austriackich Habsburgów, do których należała korona Węgier. W 1619 r. nie omieszkał skorzystać z okazji, by udzielić czynnego wsparcia Czechom w ich walce z Habsburgami i podążył ze swym wojskiem pod Wiedeń. W tym samym czasie król Polski, Zygmunt III Waza, skoligacony z Habsburgami i związany z nimi układem sojuszniczym z 1613 r., zezwolił wracającym z wojny moskiewskiej lisowczykom na interwencję w Siedmiogrodzie, wymierzoną przeciw Bethlenowi. Zawiedziony książę, który musiał wycofać się spod Wiednia, wykorzystał fakt interwencji lisowczyków do oczernienia Polski w Stambule ${ }^{1}$.

Zabiegi Gabora Bethlena trafiły na podatny grunt, gdyż stosunki polskoosmańskie weszły w fazę ostrego kryzysu. Wojna groziła już w 1617 r., kiedy to Turcy postanowili uporządkować sprawy na swym północnym pograniczu. W odpowiedzi na kolejne interwencje magnatów polskich w Mołdawii (lata 1612 i 1615-1616) oraz napady kozackie na posiadłości sułtana, armia osmańska wyruszyła w 1617 r. przeciw Polsce. Dysponujący niewielkimi siłami hetman polny koronny Stanisław Żółkiewski musiał ratować pokój za cenę niekorzystnego układu w Buszy (23 września 1617 r.), przewidującego rezygnację Polski z wpływów w Mołdawii oraz zobowiązującego Rzeczpospolitą do poskromienia Kozaków². Efektem było narzucenie im w ugodzie, zawartej 28 października $1617 \mathrm{r}$. w Olszanicy nad rzeką Rosią, ograniczenia rejestru do zaledwie 1 tysiąca mołojców i zakazu wypraw czarnomorskich. Tak ostre przepisy nie weszły wszelako w życie, gdyż już rok później Rzeczpospolita sama zaciągnęła aż 20 tys. Kozaków, potrzebnych jej dla wsparcia wyprawy królewicza Władysława Wazy na

${ }^{1} \mathrm{O}$ wyprawie lisowczyków do Siedmiogrodu zob. A. Kersten, Odsiecz wiedeńska 1619 roku, „Studia i Materiały do Historii Wojskowości” (dalej: SMHW), 10 (1964) cz. 2, s. 47-87. Gabor Bethlen w okresie wojny trzydziestoletniej kilkukrotnie występował przeciw Habsburgom na Węgrzech. Z powodu ścisłych związków między Habsburgami a Zygmuntem III Wazą, poczynania Gabora Bethlena były z niepokojem śledzone w Rzeczypospolitej. Pierwszą wojnę z Habsburgami stoczył w latach 1619-1622, wspomagając Czechów i oblegając wraz z nimi Wiedeń w 1619 r. Do jego odwrotu przyczyniła się m.in. interwencja polskich lisowczyków w Siedmiogrodzie w listopadzie 1619 r. W następnym roku okrzyknięto Gabora Bethlena królem Węgier. Konflikt został przerwany w 1622 r. przez traktat pokojowy w Nikolsburgu (Mikulov), na mocy którego książę siedmiogrodzki zrzekł się pretensji do korony węgierskiej w zamian za zdobycze terytorialne (otrzymał m.in. Koszyce). W latach 1623-1624 doszło do nowej wojny między Siedmiogrodem a Habsburgami. Walki te były na rękę Turcji Osmańskiej, która rękami Bethlena zwalczała wrogich jej Habsburgów austriackich.

${ }^{2}$ D. Skorupa, Stosunki polsko-tatarskie 1595-1623, Warszawa 2004, s. 197-201. 
Moskwę. Próba ponownego ograniczenia liczebności Kozaków rejestrowych po zakończonej wojnie (ugoda rastawicka w 1619 r.) do liczby 3 tys., wywołała tylko zrozumiałe rozgoryczenie $w$ ich szeregach. Nie myśleli też bynajmniej stosować się do zakazu wypraw morskich i owszem, w 1620 r. splądrowali wybrzeża Morza Czarnego, docierając aż pod Stambuł’ . Tatarzy nie pozostawali im zresztą dłużni, już od marca $1620 \mathrm{r}$. wpadając w granice koronne ${ }^{4}$.

W tej sytuacji, wobec fiaska wysiłków poselstw polskich w Bachczysaraju i Stambule ${ }^{5}$, zdano sobie w Polsce sprawę, że wojna jest nieunikniona. Wobec przyjaznej postawy hospodara mołdawskiego, Gaspara Graţianiego, hetman wielki koronny Stanisław Żółkiewski zdecydował się na wyprzedzające działania i wkroczył z wojskiem 2 września 1620 r. do Mołdawii. Niestety, zawiodła zarówno pomoc mołdawska, jak i kozacka. $\mathrm{W}$ tej sytuacji, po przegranej bitwie pod Cecorą, Polacy zostali zmuszeni do odwrotu. Zakończył się on robiciem wojsk polskich nad Dniestrem i śmiercią Stanisława Żółkiewskiego. Hetman polny, Stanisław Koniecpolski, poszedł do niewoli' ${ }^{6}$.

Tak spektakularna klęska wojsk polskich zachęciła młodego sułtana, Osmana II (1618-1622) do podjęcia w następnym roku walnej wyprawy przeciw Rzeczypospolitej. W jej efekcie doszło do długotrwałych zmagań pod Chocimiem, gdzie wojskom turecko-tatarskim przeciwstawiły się siły koronne, litewskie i kozackie, pod wspólnym dowództwem hetmana wielkiego litewskiego Jana Karola Chodkiewicza, a po jego śmierci Stanisława Lubomirskiego. Kampania zakończyła się porażką Turków. Sułtan musiał zadowolić się zawarciem układu, który w istocie nie wnosił nic nowego do stanu rzeczy, jaki nastał po traktacie w Buszy: Rzeczpospolita potwierdziła wycofanie się ze spraw mołdawskich i obiecała trzymać Kozaków na wodzy, a w zamian sułtan odnowił pokój i obiecał powstrzymać najazdy tatarskie ${ }^{7}$. Złożonych obietnic trudno było jednak dotrzymać, co już niebawem mieli doświadczyć na swojej skórze zarówno Polacy, jak i Turcy.

Zawarty pod Chocimiem traktat musiał zostać potwierdzony osobnym układem pomiędzy królem polskim a sułtanem. W tym celu wysłano w 1622 r. nad Bosfor koniuszego koronnego, Krzysztofa ks. Zbaraskiego. W czasie odbywania

${ }^{3}$ T. Górski, Flotylle kozackie w stużbie Jagiellonów i Wazów, Gdańsk 2006, s. 139-140.

${ }^{4}$ Skorupa, Stosunki polsko-tatarskie, s. 233.

${ }^{5}$ Wysłany w 1619 r. do Bachczysaraju Florian Oleszko, gdy nie przywiózł ze sobą zaległych „upominków”, został na rozkaz chana Dżanibeka II Gereja wtrącony do więzienia w Czufut Kale. Nie powiodła się również misja pokojowa Hieronima Otwinowskiego w Stambule, wysłanego tam późną jesienią 1619 r. - zob. L. Podhorodecki, Chanat krymski i jego stosunki z Polska w XV-XVIII wieku, Warszawa 1987, s. 135-136 i Skorupa, Stosunki polsko-tatarskie, s. 222-230 (na temat misji F. Oleszki).

${ }^{6}$ Kampania 1620 r. jest dobrze znana, stąd nie ma potrzeby omawiać jej szczegółowo. Podstawowe opracowania: R. Majewski, Cecora rok 1620, Warszawa 1970 i ostatnio: K. Śledziński, Cecora 1620, Warszawa 2007.

${ }^{7}$ Działania pod Chocimiem trwały od 2 września do 9 października 1621 r., przy czym w październiku prowadzono już rozmowy pokojowe. Na temat kampanii $1621 \mathrm{r}$. i układu, zawartego z Turkami pod Chocimiem, zob. m.in.: J. Tretiak, Historja wojny chocimskiej, Kraków 1921; L. Podhorodecki, N. Raszba, Wojna chocimska 1621 roku, Kraków 1979, L. Podhorodecki, Chocim 1621, Warszawa 1988 і ostatnio П. Сас, Хотинська війна 1621 року, Біла Церква 2012. 
swojej legacji poseł polski trafił na zmianę na tronie sułtańskim, co nieco wydłużyło prowadzenie rozmów. Sułtan Osman II został zamordowany przez zbuntowanych janczarów już w 1622 r. i Krzysztof ks. Zbaraski posłował do jego następcy, Mustafy I. Ten jednak okazał się niezdolny do rządzenia i już w 1623 r. został zdetronizowany na rzecz brata Osmana II, małoletniego Murada IV (1623-1640). Polacy usiłowali wykorzystać zamieszanie, by wprowadzić do traktatu jak najbardziej korzystne zapisy - domagali się m.in. wpływu na obsadę tronu mołdawskiego - ale ostatecznie Turcy narzucili swoją wersję układu. Niemniej, jego zawarcie oznaczało odnowienie pokoju między oboma państwami ${ }^{8}$.

Dla trwałości zawartego układu potrzeba było ograniczyć „,swawolę kozacką". Polska była poniekąd zmuszona wybierać pomiędzy przyjaźnią Kozaków a przyjaźnią Turków. Wobec jawnej niemożności pokonania Turków uznano, że łatwiej będzie poskromić Kozaków. W ten sposób niedługo po wspólnej walce pod Chocimiem, stosunki polsko-kozackie zaczęły się psuć. Po śmierci oddanego Polsce i mającego mir wśród Kozaków ich hetmana, Piotra Konaszewicza Sahajdacznego (zmarł w kwietniu 1622 r.) nie było po stronie kozackiej nikogo, kto mógłby nakłonić ziomków do przyjęcia warunków polskich. Polacy zaś żądali przede wszystkim niezaczepiania Turków i Tatarów.

Tymczasem w 1624 r. doszło na Krymie do wojny domowej. Turcy postanowili zdetronizować chana Mehmeda III Gereja i przywrócić na tron Dżanibeka II Gereja. Ku ich zdziwieniu, panujący chan stawił zbrojny opór. Co więcej, jego brat, Szahin Gerej, pozyskał sobie Kozaków i namówił ich do interwencji na Krymie. Pomoc kozacka w 1624 r. okazała się decydująca dla sukcesu obu braci. Kozacy wyruszyli w lipcu na Stambuł, paląc przedmieścia stolicy, ogołoconej z floty, która znajdowała się u wybrzeży krymskich. Z dymem poszły też tureckie miasta nad Dunajem - Braiła oraz Izmaił. W takiej sytuacji Turkom nie pozostało nic innego, jak zrezygnować z próby zmiany chana9.

Działania Kozaków stały jednak w jaskrawej sprzeczności z postanowieniami świeżo zawartego układu polsko-osmańskiego. Niepokoić musiały też kontakty kozacko-tatarskie. Zygmunt III postanowił zatem siłą doprowadzić Zaporożców do posłuszeństwa. W instrukcji przed sejmem $1625 \mathrm{r}$. ostrzegał szlachtę przed niebezpieczeństwem, płynącym ze strony Kozaków i wzywał do udzielenia pomocy hetmanowi polnemu koronnemu, Stanisławowi Koniecpolskiemu, który

\footnotetext{
${ }^{8}$ Poselstwo Krzysztofa ks. Zbaraskiego zostało opisane w poemacie Samuela Twardowskiego ze Skrzypny - zob. S. Twardowski, Przeważna legacyja Krzysztofa Zbaraskiego od Zygmunta III do sultana Mustafy, wyd. R. Krzywy, Warszawa 2000. Na temat poselstwa K. Zbaraskiego zob. m.in. D. Kołodziejczyk, Otoman-Polish Diplomatic Relations (15th - 18th century). An Annotated Edition of 'Ahdnames and Other Documents, Leiden-Boston-Köln 2000, s. 133-135. Zmiana na tronie tureckim w $1623 \mathrm{r}$. spowodowała, iż Turcy wystawili dwa dokumenty pokojowe, w imieniu dwóch kolejnych sułtanów, Mustafy I i Murada IV - zob. 'Ahdname sułtana Mustafy I dla króla Zygmunta III, Stambuł, 12-21 II 1623, tamże, dokument 37, s. 388-401 i 'Ahdname sułtana Murada IV dla króla Zygmunta III, Stambuł, 10 X 1623, tamże, dokument 38, s. 402-418.

${ }^{9}$ M. Berindei, La Porte Ottomane face aux Cosaques Zaporogues. 1600-1637, „Harvard Ukrainian Studies", 1977, t. 1, z. 3, s. 293-295, T. Górski, Flotylle, Gdańsk 2006, s. 141, W.A. Serczyk, Na dalekiej Ukrainie. Dzieje Kozaczyzny do 1648 roku, Kraków 2008, s. 256-258.
} 
otrzymał zadanie spacyfikowania Kozaków. Hetman wyruszył na czele 8 tys. żołnierzy z Baru na Podolu w stronę Ukrainy. Kozacy stawili zbrojny opór pod dowództwem Marka Żmajły. W październiku 1625 r., po utarczkach pod Kaniowem, Polacy zepchnęli Kozaków w rejon Kryłowa. Tu przystąpiono do rokowań. Hetman dążył do pogodzenia się z Kozakami, doceniając ich siłę bojową i przydatność dla Rzeczypospolitej. Niemniej warunki stawiał twarde: rejestr miał być ograniczony do 5 tys., a wszyscy, którzy znaleźliby się poza nim, mieli wrócić do pracy na roli. Miano też wydać przywódców wypraw na Morze Czarne oraz posłów do Moskwy, a także całą korespondencję między Kozakami a Moskwą. Na tak ciężkie warunki Kozacy nie zamierzali zgadzać się, nie spróbowawszy pierwej oporu. Mógł on skłonić Polaków do ustępstw.

Hetman, nie mając wyboru, zaatakował obóz kozacki. Polska przewaga zmusiła powstańców kozackich do odwrotu: wycofali się spod Kryłowa nad Jezioro Kurukowskie. Odwrót odbywał się wśród ciągłych walk z Polakami, którzy usiłowali przełamać tabor kozacki. Ataki nie przyniosły jednak spodziewanego efektu, a zamiast tego przysporzyły strat, zwłaszcza w jeździe i wojskach pieszych cudzoziemskiego autoramentu. Walki dały się wszakże we znaki także drugiej stronie. Kozacy, widząc nieustępliwość wojsk koronnych, stracili wiarę w sens dalszej walki. W obozie kozackim doszło do przewrotu - usunięto Marka Żmajłę z naczelnego dowództwa, które powierzono Michałowi Doroszence. Był on współpracownikiem Piotra Konaszewicza Sahajdacznego i sprzyjał Polsce. Stanąwszy teraz na czele Kozaków, podpisał 5 listopada 1625 r. na uroczysku Niedźwiedzie Łozy nad Jeziorem Kurukowskim ugodę z Polakami. Stanowiła ona m.in., iż rejestr kozacki ma wynosić 6 tys. ludzi - co, jak widać, było sukcesem kozackim wobec pierwotnych żądań polskich. Kozaków zobowiązano jednak do spalenia czajek, na których wyprawiali się na Morze Czarne. Zakazano im takich wypraw, a jednocześnie zobowiązano rejestrowych, by nie tylko strzegli Ukrainy przed Tatarami, ale też pilnowali innych Kozaków, by ci nie wyruszali na Morze Czarne. Kozakom, usuniętym z rejestru, pozostawiono prawa kozackie, zabraniając im jednak organizowania się w oddziały zbrojne i zobowiązując do mieszkania tylko w dobrach królewskich. Ustanowiono też urząd „starszego” nad Kozakami rejestrowymi. Miał on być wybierany przez Kozaków, ale zatwierdzany przez władze polskie - króla albo hetmana wielkiego koronnego. Miał też odpowiadać przed Polakami za zachowanie się tak rejestrowych, jak i nierejestrowych Kozaków. Oczywiście zabroniono też Kozakom utrzymywania jakichkolwiek kontaktów z państwami obcymi. W zamian objęto amnestią wszystkich uczestników powstania i odstąpiono od żądania wydania przywódców ostatnich wypraw czarnomorskich. Osiągnięto zatem dość korzystne dla obu stron porozumienie, które w najbliższym czasie zapewniło owocne współdziałanie polsko-kozackie przeciw Tatarom $^{10}$.

Jak bardzo współdziałanie to było potrzebne, dowiodły już najbliższe wypadki. Oto chan Mehmed III Gerej, w ramach odnawiania swych przyjacielskich sto-

${ }^{10} \mathrm{Na}$ temat kampanii 1625 r. i ugody kurukowskiej zob. М. Грушевський, Історія УкраӥниРуси, t. 7, Київ 1995, s. 543-561 і Serczyk, Na dalekiej Ukrainie, s. 260-266. 
sunków z sułtanem, przedsięwziął w styczniu 1626 r. wielką wyprawę na Polskę. Tatarzy wdarli się pod Tarnopol, gdzie założyli główny obóz (kosz). Stamtąd rozpuścili czambuły aż po Łuck, Włodzimierz i Lwów. W dalszej kolejności spustoszone zostały okolice Trembowli i Halicza. Niespodziewany najazd spowodował ogromne zniszczenia na Rusi. Zanim hetman Stanisław Koniecpolski zdołał zebrać armię, Tatarzy ruszyli z jasyrem do siebie. Udało się co prawda dopaść i pokonać tylną straż tatarską na przeprawie przez Dniestr pod Uściem, nie zmieniło to jednak ogólnego bilansu - kampania zakończyła się niepowodzeniem polskim $^{11}$. Dopiero udane współdziałanie z Kozakami umożliwiło jesienią $1626 \mathrm{r}$. odniesienie znaczącego sukcesu nad Tatarami, kiedy to pod Białą Cerkwią regimentarz Stefan Chmielecki zdobył kosz tatarski i wkrótce potem rozgromił grasującą na Ukrainie ordę ${ }^{12}$.

Opisane wyżej wypadki są dość dobrze rozpoznane przez polską literaturę przedmiotu. Niemniej, dysponujemy dla tego okresu źródłami, które bywają słabo wykorzystane. Należą do nich listy, jakie wysyłał biskup krakowski Marcin Szyszkowski do ówczesnego wojewody kijowskiego, Tomasza Zamoyskiego. Przechowywane są one obecnie w Archiwum Głównym Akt Dawnych w Warszawie, w zespole 358 (Archiwum Zamoyskich). Po sygnaturą 384 znajdujemy tam dwanaście listów Marcina Szyszkowskiego do Tomasza Zamoyskiego z lat 1622-1629 oraz jeden niedatowany list Mikołaja Szyszkowskiego ${ }^{13}$ do Tomasza Zamoyskiego. Pierwszy list, pochodzący z 1622 r., biskup Marcin Szyszkowski sygnował wspólnie z Rafałem Leszczyńskim i Mikołajem Firlejem z Dąbrowicy. Rafał Leszczyński był wojewodą bełskim, zaś Mikołaj Firlej sprawował ówcześnie funkcje kasztelana bieckiego i starosty lubelskiego ${ }^{14}$.

Listy są oryginalne i uporządkowane chronologicznie. Cała korespondencja obejmuje następujące listy:

1. Marcin Szyszkowski, Rafał Leszczyński i Mikołaj Firlej z Dąbrowicy do Tomasza Zamoyskiego, Lublin, 8 X 1622, s. 1-2.

2. Marcin Szyszkowski do Tomasza Zamoyskiego, Iłża, 15 IX 1623, s. 3-5.

3. Marcin Szyszkowski do Tomasza Zamoyskiego, Wawrzeńczyce ${ }^{15}, 2$ XII 1624, s. 6-9.

${ }^{11}$ Co prawda sami Polacy starali się przedstawić zimową kampanię 1626 r. jako swój sukces. Na temat tych wydarzeń zob. Podhorodecki, Chanat krymski, s. 150-151.

${ }^{12}$ Bitwę pod Białą Cerkwią stoczono 9 października 1626 r. Zob. M. Domagała, Relacja z kampanii białocerkiewskiej 1626 r. przeciwko Tatarom autorstwa Jana Dobrocieskiego, w: Staropolska sztuka wojenna XVI-XVII wieku, red. M. Nagielski, Warszawa 2002, s. 237-248 i Podhorodecki, Chanat krymski, s. 151.

${ }^{13}$ Mikołaj Szyszkowski (zm. 1643), bratanek Marcina Szyszkowskiego, został w 1633 r. biskupem warmińskim. Zob. P. Nitecki, Biskupi Kościoła w Polsce w latach 965-1999. Stownik biograficzny, Warszawa 2000, s. 436.

${ }^{14}$ Rafał Leszczyński h. Wieniawa (1579-1636), od 1619 r. wojewoda bełski. Zob. M. Sipayłł, Leszczyński Rafat, w: Polski Stownik Biograficzny (dalej: PSB), t. 17, Wrocław 1972, s. 135-139. Mikołaj Firlej h. Lewart (1588-1635). W 1633 r. został wojewodą sandomierskim. Zob. K. Lepszy, Firlej Mikołaj, PSB, t. 7, Kraków 1948-1958, s. 15.

${ }^{15} \mathrm{~W}$ oryginale: Wawrzyńczyce. 
4. Marcin Szyszkowski do Tomasza Zamoyskiego, Bodzentyn ${ }^{16}, 2$ XII 1625, s. 1013.

5. Marcin Szyszkowski do Tomasza Zamoyskiego, Bodzentyn, 4 III 1626, s. 1417.

6. Marcin Szyszkowski do Tomasza Zamoyskiego, Bożęcin, 31 III 1626, s. 1819.

7. Marcin Szyszkowski do Tomasza Zamoyskiego, Lublin, 27 VI 1627, s. 20-22.

8. Marcin Szyszkowski do Tomasza Zamoyskiego, Bożęcin, 31 X 1627, s. 2324.

9. Marcin Szyszkowski do Tomasza Zamoyskiego, Iłża, 1 VII 1628, s. 25-28.

10. Marcin Szyszkowski do Tomasza Zamoyskiego, Kraków, 10 X 1628, s. 2931.

11. Marcin Szyszkowski do Tomasza Zamoyskiego, Kielce, 12 XI 1628, s. 3233.

12. Marcin Szyszkowski do Tomasza Zamoyskiego, Wałowice, 14 V 1629, s. 3435.

13. Mikołaj Szyszkowski do Tomasza Zamoyskiego, Kraków, bd., s. 36-37.

Biskup Marcin Szyszkowski poruszał w swojej korespondencji z Tomaszem Zamoyskim wiele różnych zagadnień, jednak w tym przypadku interesują nas sprawy kozacko-tatarskie, w których uczestniczył wojewoda kijowski. Pozostaje rzeczą ciekawą i godną bliższego zbadania, na ile episkopat koronny interesował się sprawami zagrożenia granic południowo-wschodnich i jakie księża biskupi przewidywali środki zaradcze, mające zabezpieczyć Rzeczpospolitą. Z tego powodu zdecydowaliśmy się na edycję trzech listów spośród tego zbioru:

1. Marcin Szyszkowski do Tomasza Zamoyskiego, Iłża, 15 IX 1623, s. 3-5.

2. Marcin Szyszkowski do Tomasza Zamoyskiego, Bodzentyn, 2 XII 1625, s. 1013.

3. Marcin Szyszkowski do Tomasza Zamoyskiego, Bodzentyn, 4 III 1626, s. 14 17.

Autorem wydawanych przez nas listów był biskup krakowski Marcin Szyszkowski herbu Ostoja (1554-1630). Pochodził z niezbyt bogatej rodziny szlacheckiej, osiadłej w Małopolsce (urodził się w Iłży). Obrał karierę duchowną, co umożliwiło mu wejście do najwyższych warstw społeczeństwa szlacheckiego. Studiował w kolegium jezuickim w Pułtusku, następnie w Akademii Krakowskiej, wreszcie w Rzymie oraz Bolonii i Padwie, zdobywając doktorat obojga praw. Był proboszczem w rodzinnej Iłży, a od 1587 r. kanonikiem w katedrze krakowskiej. Związał się z dwoma biskupami krakowskimi: Piotrem Myszkowskim (1577-1591) i kardynałem Bernardem Maciejowskim (1600-1606). W 1603 r. został biskupem koadiutorem łuckim przy Stanisławie Gomolińskim, a po jego śmierci w 1604 r. objął tę diecezję. Biskupstwo łuckie liczyło się do pośledniejszych w Koronie, było jednak dobrym punktem wyjścia do dalszej kariery. I rzeczywiście, już w 1606 r. Marcin Szyszkowski przeszedł na biskupstwo płockie,

\footnotetext{
${ }^{16} \mathrm{~W}$ oryginale: Bodzencin. Podobnie w liście z 4 marca $1626 \mathrm{r}$.
} 
zaś w 1616 r. król Zygmunt III przeniósł go do Krakowa, któremu pasterzował do swojej śmierci w 1630 r. Pochowany został w katedrze wawelskiej, gdzie jego bratanek, Mikołaj Szyszkowski, wystawił mu nagrobek ${ }^{17}$.

Jako biskup, Marcin Szyszkowski odznaczał się wielką energią i gorliwym wdrażaniem reformy trydenckiej w podległych mu diecezjach. Reformację zwalczał w pismach teologicznych. Wizytował diecezje i zwoływał synody - w Płocku w 1612 r., w Krakowie w 1621 r. Gorliwie popierał zakon Jezuitów, widząc w nim narzędzie do walki z protestantyzmem. Jego zasługą było sprowadzenie Jezuitów do Płocka w 1611 r. i ufundowanie tam ich kolegium w 1616 r. W tym samym czasie założył też kolegium jezuickie w Łomży, chcąc objąć całą diecezję działaniem szkolnictwa tego zakonu ${ }^{18}$. Marcin Szyszkowski oddawał się też działalności budowlanej, wznosząc m.in. pałac biskupów w Płocku, remontując zamek biskupów płockich w Pułtusku oraz fundując kościół w rodzinnej Iłży. Sam Pułtusk doczekał się także wydania wilkierza przez biskupa w 1615 r., po pożarze miasta $^{19}$.

Istotnym dla nas jest fakt, że Marcin Szyszkowski wypełniał także rzetelnie swoje obowiązki jako senator i uczestniczył w życiu publicznym Rzeczypospolitej. Jeszcze w 1605 r. wyruszył wraz z marszałkiem wielkim koronnym Zygmuntem Myszkowskim do Grazu po Konstancję Habsburżankę, drugą żonę Zygmunta III Wazy ${ }^{20}$. W 1607 r. był jednym z sygnatariuszy listu do hetmana wielkiego litewskiego Jana Karola Chodkiewicza, w którym konsultowano z nim sposób zapłaty żołnierzom ${ }^{21}$. Synod duchowieństwa w Płocku w 1612 r. zwołał głównie w celu zebrania kontrybucji na wojnę moskiewską ${ }^{22}$. Wotując na sejmach w 1616 i 1618 r., zabierał głos w sprawach wojskowych, popierając pomysły zwiększenia liczby wojska kwarcianego i uderzenia prewencyjnego na Tatarów - choć zarazem doradzał wycofanie się z Mołdawii, jako niemożliwej do utrzymania i potępiał wyprawy magnackie do tego kraju ${ }^{23}$. W 1619 r. król konsultował z biskupem

${ }^{17}$ Podstawowe informacje na temat Marcina Szyszkowskiego zob. m.in.: bp E. Ozorowski, Szyszkowski Marcin h. Ostoja (1554-1630), w: Stownik polskich teologów katolickich, t. 4, red. H.E. Wyczawski, Warszawa 1983, s. 296-298 i Nitecki, Biskupi Kościoła w Polsce w latach 965-1999, s. 436.

${ }^{18}$ D. Kisiel, Recepcja reformy trydenckiej $w$ diecezji płockiej, Pultusk 2004, s. 80-81.

${ }^{19}$ Niestety, ten wilkierz, zwany „plebiscytem”, nie zachował się do naszych czasów - zob. Z. Morawski, Przywileje miasta Puttuska, w: Pultusk. Studia i materiały z dziejów miasta i regionu, t. 7, red. J. Szczepański, Pułtusk 2007, s. 22.

${ }^{20}$ Posłowie ci w imieniu króla zawarli 23 października 1605 r. umowę przedślubną z Konstancją Habsburżanką - zob. H. Wisner, Dyplomacja polska w latach 1572-1648, w: Historia dyplomacji polskiej, t. 2, red. G. Labuda, Wrocław 1982, s. 31; H. Wisner, Zygmunt III Waza, Wrocław 2006, s. 94 i J. Besala, Matżeństwa królewskie. Władcy elekcyjni, Warszawa 2007, s. 97-98.

${ }^{21}$ Innymi sygnatariuszami tego listu byli Stanisław Warszycki i Hrehory Chodkiewicz - zob. M. Szyszkowski, S. Warszycki i H. Chodkiewicz do J.K. Chodkiewicza, Brześć Litewski, 25 X 1607 r., w: Korrespondencye Jana Karola Chodkiewicza, wyd. W. Chomętowski, Warszawa 1875, nr 3, s. 104105. Zob. P. Gawron, Hetman koronny w systemie ustrojowym Rzeczypospolitej w latach 1581-1646, Warszawa 2010, s. 387.

${ }^{22}$ Kisiel, Recepcja reformy trydenckiej, s. 82.

${ }^{23}$ Gawron, Hetman koronny, s. 301. 
pomysł wysłania części wojsk polskich nad granicę siedmiogrodzką, by zapobiec ewentualnej agresji ze strony Gabora Bethlena ${ }^{24}$. Wiosną następnego roku biskup krakowski stał się jednym z adresatów skarg szlachty krakowskiej na bezprawne zaciągi cesarskie wśród lisowczyków i popełniane przez tych ostatnich przestępstwa $^{25}$. Szlachta miała powody, by zwracać się właśnie do biskupa krakowskiego, gdyż to z nim omawiał zaciągi lisowczyków na służbę cesarską biskup wrocławski, Karol Habsburg ${ }^{26}$. Wobec zagrożenia tureckiego po klęsce cecorskiej wystąpił Marcin Szyszkowski 1 grudnia 1620 r. z apelem do patriarchy jerozolimskiego Teofanesa, przebywającego wtedy wśród Kozaków na Ukrainie, aby nakłonił Zaporożców do udzielenia pomocy Polsce przeciw wyznawcom islamu ${ }^{27}$. Te, podane tylko dla przykładu, przejawy działalności publiczno-politycznej biskupa Marcina Szyszkowskiego, dowodzą, iż rozumiał potrzeby Rzeczypospolitej.

Odbiorcą listów biskupa krakowskiego był Tomasz Zamoyski (1594-1638), jedyny syn i sukcesor kanclerza i hetmana wielkiego koronnego, Jana Zamoyskiego. W omawianym okresie lat 1623-1626 pełnił on już wysokie godności w Rzeczypospolitej. Odziedziczywszy po ojcu ogromny majątek, wchodził do pierwszych szeregów magnaterii koronnej. Ułatwiało mu to niezmiernie karierę polityczną, a nawet - można zaryzykować takie twierdzenie - było główną przyczyną tejże kariery. W opinii współczesnych Tomasz Zamoyski nie cieszył się bowiem zbyt dobrą sławą i wręcz uważano go za człowieka słabego, o nikłych zdolnościach umysłowych, który w niczym zgoła nie przypominał wybitnego ojca ${ }^{28}$. Nie przeszkadzało mu to jednak żywić wielkich ambicji i piąć się po szczeblach kariery. Zgromadził w swym ręku wiele dochodowych starostw - m.in. knyszyńskie, goniądzkie, sokalskie i kałuskie. W 1628 r. Tomasz Zamoyski otrzymał starostwo generalne krakowskie ${ }^{29}$. Wcześniej - m.in. w 1622 r. - bywał deputatem do Trybunału Koronnego w Lublinie ${ }^{30}$-śladem tej jego działalnościjest zachowany w przytaczanej korespondencji list Marcina Szyszkowskiego, Rafała Leszczyńskiego i Mikołaja Firleja do Tomasza Zamoyskiego z 8 października 1622 r. ${ }^{31}$ Już w 1618 r. otrzymał godność wojewody bełskiego, zaś w 1619 r. przejął po Stanisławie Żółkiewskim województwo kijowskie ${ }^{32}$. Urząd ten pełnił do roku 1628 , kiedy to

${ }^{24}$ Tamże, s. 123.

${ }^{25}$ Tamże, s. 227.

${ }^{26}$ R. Lolo, Rzeczpospolita wobec wojny trzydziestoletniej. Opinie i stanowiska szlachty polskiej (1618-1635), Pułtusk 2004, s. 114.

${ }^{27}$ Wisner, Zygmunt III Waza, s. 188. Biskup szedł tu w ślady króla, który zwrócił się do patriarchy Teofanesa z takimże apelem trzy tygodnie wcześniej. Jak twierdzi J. Tretiak, Historja, s. 45, biskup Marcin Szyszkowski wyprawił pod Chocim w 1621 r. własną stukonną chorągiew husarską.

${ }^{28}$ W. Czapliński, Władysław IV i jego czasy, Kraków 2008, s. 117.

${ }^{29}$ Urzędnicy województwa krakowskiego XVI-XVIII wieku. Spisy, oprac. S. Cynarski i A. Falniowska-Gradowska, Kórnik 1990, s. 99.

${ }^{30}$ M. Dobrowolska, Trybunat Koronny w Lublinie 1578-1794, Lublin 1994, s. 42.

${ }^{31}$ M. Szyszkowski, R. Leszczyński i M. Firlej do T. Zamoyskiego, Lublin, 8 X 1622 r., AGAD, AZ, sygn. 384, s. 1-2.

${ }^{32}$ Nominacja na województwo kijowskie nastąpiła 11 stycznia 1619 r. Zob. Urzędnicy województw kijowskiego i czernihowskiego XV-XVIII wieku. Spisy, oprac. E. Janas, W. Kłoczewski, Kórnik 2002, s. 67. 
awansował na podkanclerstwo koronne. Promotorem tej nominacji był świeżo kreowany na kanclerza wielkiego koronnego Jakub Zadzik, ks. biskup chełmiński, który chciał mieć przy boku wpływowego, ale niezbyt energicznego i niezagrażającego mu kolegę na urzędzie ${ }^{33}$. Po przesunięciu przez Władysława IV Jakuba Zadzika na biskupstwo krakowskie w 1635 r., Tomasz Zamoyski w drodze naturalnego awansu otrzymał pieczęć większą koronną ${ }^{34}$.

Największym i niespełnionym marzeniem Tomasza Zamoyskiego było jednak zdobycie buławy. Tradycyjnie już bowiem przewagi militarne były największą chlubą stanu rycerskiego, a że ojciec Tomasza Zamoyskiego miał na tym polu niemałe osiągnięcia, syn pragnął mu dorównać. Angażował się zatem Tomasz Zamoyski w rozmaite kampanie wojenne, często nie szczędząc własnego zdrowia i pieniędzy, którymi opłacał wojska, wystawiane na potrzebę Rzeczypospolitej. Widzimy go zatem w niefortunnej kampanii orynińskiej Stanisława Żółkiewskiego przeciw Tatarom w $1618 \mathrm{r}^{35}$ Trzy lata później nie zdążył z wojskiem pod Chocim, gdzie jednak znajdowała się część jego żołnierzy, a on sam starał się powstrzymywać Tatarów pod Tarnopolem ${ }^{36}$. Uczestniczył w walkach z Kozakami i Tatarami w latach 1625-1626, o czym niżej, a także w kampanii przeciw Szwedom w Prusach Królewskich i w bitwie pod Gniewem w 1626 r., gdzie miał okazję walczyć pod okiem samego Zygmunta $\mathrm{III}^{37}$. Nie poskapił też własnych funduszy, przyprowadzając na pole bitwy 300 kozaków i 220 piechoty $^{38}$. Nieste-

${ }^{33}$ J. Dorobisz, Jakub Zadzik (1582-1642), Opole 2000 s. 165. Jakub Zadzik otrzymał pieczęć większą podczas obrad sejmu w Warszawie w dniu 10 lipca 1628 r. Nazajutrz pieczęć mniejszą otrzymał Tomasz Zamoyski. Zob. Urzędnicy centralni i nadworni Polski XIV-XVIII wieku. Spisy, oprac. K. Chłapowski i in., red. A. Gąsiorowski, Kórnik 1992, s. 111.

${ }^{34}$ „Awans” Jakuba Zadzika na biskupstwo krakowskie był faktycznie odsunięciem go na boczny tor, gdyż król był rozczarowany rolą, jaką odegrał kanclerz w czasie rokowań polsko-szwedzkich w Sztumskiej Wsi. Podczas gdy Władysław IV parł do wojny ze Szwecją, chcąc odzyskać dziedziczną koronę, kanclerz realizował interesy Rzeczypospolitej i zabiegał o zawarcie korzystnego rozejmu. Zob. Dorobisz, Jakub Zadzik, s. 243-244 i Czapliński, Władysław IV, s. 114-117 (o „trifolium” rządzącym Polską u progu panowania Władysława IV: kanclerzu wielkim koronnym i biskupie chełmińskim Jakubie Zadziku, hetmanie wielkim koronnym Stanisławie Koniecpolskim i wojewodzie ruskim Stanisławie Lubomirskim). Kanclerstwo wielkie koronne objął Tomasz Zamoyski 30 listopada 1635 r. - Urzędnicy centralni i nadworni Polski XIV-XVIII wieku. Spisy, oprac. K. Chłapowski i in., red. A. Gąsiorowski, Kórnik 1992, s. 56.

${ }^{35}$ Tomasz Zamoyski przyprowadził pod Orynin 150 husarzy, 400 kozaków i 200 piechoty. Zob. P. Nowatkiewicz, Orynin 28 IX 1618, Zabrze 2009, s. 32 i n. i 60-61 (aneks źródłowy).

${ }^{36}$ S. Żurkowski, Żywot Tomasza Zamojskiego kanclerza w. koronnego, Lwów 1860, s. 82-86, Tretiak, Historja, s. 128.

${ }^{37} \mathrm{~W}$ czasie narady wojennej w Warszawie 5 sierpnia 1626 r. rozważano powierzenie Tomaszowi Zamoyskiemu dowództwa nad wojskiem do czasu nadejścia hetmana Stanisława Koniecpolskiego, ale kandydat odrzucił tę propozycję. Jak uważa autor monografii bitwy gniewskiej, Tomaszowi Zamoyskiemu bardziej chodziło wówczas o buławę, niż o czasowe regimentarstwo - zob. J. Teodorczyk, Bitwa pod Gniewem (22 IX - 29 IX - 1 X 1626). Pierwsza porażka husarii, SMHW, 12 (1966) cz. 2, s. 74. O udziale Tomasza Zamoyskiego w tej kampanii zob. także Żurkowski, Żywot Tomasza Zamojskiego, s. 106-114.

${ }^{38}$ Teodorczyk, Bitwa pod Gniewem, s. 93-95. 
ty, mimo szczerych chęci, brakowało mu talentów wojskowych i król pozostał nieczuły na zabiegi Tomasza Zamoyskiego i nie obdarzył go buławą. Wprawdzie w 1632 r. mianował hetmanem wielkim koronnym Stanisława Koniecpolskiego i rozważał nawet przekazanie buławy mniejszej Tomaszowi Zamoyskiemu, ale nie zdążył podjąć decyzji ${ }^{39}$. Dopiero Władysław IV powierzył hetmaństwo polne w 1633 r. swemu ulubieńcowi, Marcinowi Kazanowskiemu, a po jego rychłej śmierci w 1636 r. oddał buławę Mikołajowi Potockiemu ${ }^{40}$.

Wyrazem wspomnianych aspiracji wojskowych Tomasza Zamoyskiego był jego udział w walkach z Kozakami i Tatarami jesienią 1625 i zimą 1626 r. Napięcia wśród Kozaków miała rozstrzygnąć komisja, powołana przez sejm, w której znalazł się także Tomasz Zamoyski ${ }^{41}$. Skoro zatem we wrześniu 1625 r. hetman polny koronny Stanisław Koniecpolski wyruszył z wojskiem dla poskromienia Kozaków, Tomasz Zamoyski wyjechał w ślad za nim i dogonił go 3 października 1625 r. za Kaniowem ${ }^{42}$. Po zerwaniu przez Kozaków rokowań, 28 października nastąpił atak polski na tabor kozacki, rozłożony nad rzeczką Cybulnik. W tej walce osobiście uczestniczył Tomasz Zamoyski, prowadząc prawe skrzydło polskie. Przewaga po stronie atakujących była tak znaczna, że Tomasz Zamoyski mógł sobie pozwolić na osobiste kierowanie ogniem artyleryjskim. Udało mu się też uniknąć bezpośredniego zagrożenia, gdyż w porę odparł dwie próby, jakie podjęli Kozacy, by dotrzeć do stanowisk polskiej artylerii43 ${ }^{4}$ Kilka dni później Tomasz Zamoyski ponownie był w ogniu walk, prowadząc własną chorągiew husarską. Nareszcie 3 listopada przystąpiono do rokowań, w których wojewoda kijowski także z racji swojego urzędu - odegrał znaczącą rolę ${ }^{44}$. Ostatecznie, jak wiemy, doszło do podpisania ugody kurukowskiej i zakończenia walk.

${ }^{39}$ Stanisław Koniecpolski otrzymał buławę wielką na kilka tygodni przed śmiercią króla - zob. M. Nagielski, Stanisław Koniecpolski herbu Pobóg (ok. 1592-1646) hetman wielki, w: Poczet hetmanów Rzeczypospolitej. Hetmani koronni, red. M. Nagielski, Warszawa 2005, s. 153. P. Gawron, Hetman koronny, s. 135. Innym kandydatem, którego król brał pod uwagę, był Marcin Kazanowski. Na jego temat zob. A. Przyboś, Kazanowski Marcin, PSB, t. 12, Wrocław 1966-1967, s. 257-259.

${ }^{40}$ Mikołaj Potocki awansował na urząd hetmana polnego koronnego 12 lutego 1637 r. Zob. M. Nagielski, Mikołaj Potocki herbu Pilawa (ok. 1593-1651) hetman wielki koronny, w: Poczet hetmanów, red. M. Nagielski, Warszawa 2005, s. 161; W. Majewski, Potocki Mikołaj, PSB, t. 28, Wrocław 1984, s. 105-110.

${ }^{41}$ Komisję do spraw ułożenia spraw kozackich z udziałem Tomasza Zamoyskiego powołał sejm w 1623 r. Zob. konstytucja „Komisja kozacka”, Volumina Legum, t. 3, wyd. J. Ohryzko, Petersburg 1859 , s. 216. Ponieważ komisja ta nie doszła do skutku, kolejny sejm w 1624 r. reaktywował ją - zob. konstytucja „Komisja kozacka”, tamże, s. 223. Zob. J. Dorobisz, Sejm nadzwyczajny z 1624 roku, Opole 1994, s. 98.

${ }^{42}$ Żurkowski, Żywot Tomasza Zamojskiego, s. 96; Serczyk, Na dalekiej Ukrainie, s. 262. Wojewoda kijowski przywiódł ze sobą do obozu 300 żołnierzy i 5 armat - zob. Грушевський, Історія Украӥни-Руси, t. 7, s. 546.

${ }^{43}$ Żurkowski, Żywot Tomasza Zamojskiego, s. 97-98; Serczyk, Na dalekiej Ukrainie, s. 263264.

${ }^{44}$ Tomasz Zamoyski przyjmował u siebie posłów kozackich i prowadził korespondencję z ich hetmanem - zob. M. Żmajło do T. Zamoyskiego, obóz pod Kurukowem, 3 XI 1625 r., w: Żurkowski, Żywot Tomasza Zamojskiego, s. 101-102 i T. Zamoyski do Kozaków, obóz na Niedźwiedzich Łozach, 3 XI 1625 r., tamże, s. 102. 
Kampania jesienna 1625 r. przysporzyła zatem sławy Tomaszowi Zamoyskiemu, choć nie był on głównym aktorem wydarzeń. Nie da się tego niestety powiedzieć o najeździe tatarskim zimą $1626 \mathrm{r}$. Tomasz Zamoyski nie brał wtedy udziału w walkach, a jego biograf zapisał na konto wojewody dokonania jego protegowanego, Stefana Chmieleckiego ${ }^{45}$. Słusznie zatem miał biskup krakowski okazję do ubolewania w marcu 1626 r. nad klęską, poniesioną z rąk „,pogańskich”.

Wszystkie trzy publikowane listy datował biskup krakowski ze swych małopolskich rezydencji - Iłży i Bodzentyna. Pierwszy z listów napisał Marcin Szyszkowski w Iłży, 15 września 1623 r. W Rzeczypospolitej czekano wtedy na wyniki poselstwa Krzysztofa ks. Zbaraskiego do Stambułu. Stosunki polsko-tureckie stanowią też główny temat tego listu. Biskup krakowski przekazywał wojewodzie kijowskiemu informację o wystosowaniu przez wielkiego wezyra listów do posła polskiego i do króla. Powszechnie - i jak się miało okazać, słusznie - domyślano się wówczas pomyślnego zakończenia rozmów i zawarcia pokoju z Osmanami. Biskup krakowski zdawał sobie sprawę z rebelii Abazy paszy przeciw rządowi osmańskiemu i z jej możliwych skutków. Niepokoił się natomiast klęską oddziałów lisowskich na służbie cesarskiej oraz zapowiedzią przysłania posiłków tureckich dla księcia siedmiogrodzkiego, który toczył wówczas wojnę z Habsburgami austriackimi.

Drugi z publikowanych listów nosi datę 2 grudnia 1625 r. i wysłany został z Bodzentyna. Jest on niewątpliwie reakcją biskupa na wieści o zakończonych miesiąc wcześniej walkach z Kozakami. Nie przynosi on istotnych informacji na temat samych walk i rokowań kurukowskich, zdradza jednak bardzo życzliwy stosunek Marcina Szyszkowskiego do Tomasza Zamoyskiego. Biskup krakowski gratuluje wojewodzie kijowskiemu udziału w kampanii i chwali jego zaangażowanie dla dobra Ojczyzny. Zarazem frasuje się jednak wiadomościami o osobistym narażaniu się wojewody na niebezpieczeństwo utraty zdrowia lub życia. Wyraża przy tym przekonanie, iż osobisty udział w walce tak wysokiego rangą dygnitarza nie jest konieczny, zwłaszcza iż Tomasz Zamoyski nie miał wówczas męskiego potomka i jego ewentualna śmierć mogłaby przedwcześnie zakończyć żywot całego $\operatorname{rodu}^{46}$. Zapowiadał też biskup wystąpienie w sprawie Tomasza Zamoyskiego na najbliższym sejmiku województwa krakowskiego, aby szlachta zechciała prosić króla o wynagrodzenie zasług wojewody kijowskiego ${ }^{47}$. Treść listu jest zatem dość kurtuazyjna i zdradza wielki szacunek, jaki żywił biskup dla magnata. Wię-

\footnotetext{
${ }^{45}$ Żurkowski, Żywot Tomasza Zamojskiego, s. 104-106.

${ }^{46}$ Istotnie, jedyny syn Tomasza i Katarzyny z Ostrogskich Zamoyskich, Jan „Sobiepan”, urodzić się miał dopiero 9 kwietnia $1627 \mathrm{r}$.

${ }^{47}$ Co prawda biskup Marcin Szyszkowski nie sprecyzował, jaki sejmik miał na myśli, ale z racji sprawowanego przezeń urzędu senatorskiego nie ulega wątpliwości, że chodziło o sejmik proszowicki województwa krakowskiego. W instrukcji sejmiku przedsejmowego w Proszowicach z 16 grudnia 1625 r. znajdujemy rzeczywiście polecenie podziękowania hetmanowi i innym uczestnikom wyprawy przeciw Kozakom, jednak bez imiennego wymienienia Tomasza Zamoyskiego - zob. Instrukcja dana postom na sejm z sejmiku województwa krakowskiego w Proszowicach 16 grudnia 1625 r., w: Akta sejmikowe województwa krakowskiego, t. 2, 1621-1660, wyd. A. Przyboś, Wrocław 1955, nr XIV, s. 50.
} 
cej informacji politycznych przynosi ceduła, dodana na osobnej kartce. Marcin Szyszkowski zdradza w niej nie tylko zainteresowanie dobrem Rzeczypospolitej, ale też zrozumienie jej potrzeb i gotowość do koniecznych poświęceń. Dopytuje zatem o pozostawienie wojska koronnego na Ukrainie, które miałoby egzekwować wykonywanie przez Kozaków narzuconych im warunków ugody, a przede wszystkim nie dopuszczać do ich wypraw morskich, które mogłyby sprowokować Turcję i Tatarów do odwetu. Wskazuje też na konieczność nałożenia nowych podatków z uwagi na niebezpieczeństwo szwedzkie. Gustaw Adolf zaatakował w 1625 r. Rzeczpospolitą w Inflantach i wtargnął do Kurlandii, odnosząc niespodziewanie duże sukcesy ${ }^{48}$. Zapowiadało to ciężką wojnę, jakkolwiek na razie teatr działań był odległy. Biskup martwił się jednak możliwościami płatniczymi kraju, ograniczonymi po kilku latach panującej zarazy. Proponował też, by szlachta zgodziła się na płacenie podatku od obrotu towarowego, który co prawda naruszałby jej przywileje stanowe, ale byłby koniecznym $\mathrm{i}$ istotnym wsparciem zagrożonego państwa. Zabiegał też Marcin Szyszkowski u Tomasza Zamoyskiego o poparcie dla tego pomysłu.

Ostatni z prezentowanych listów wysłał Marcin Szyszkowski 4 marca 1626 r. z Bodzentyna. List napisany był pod wrażeniem niedawnego najazdu tatarskiego. Biskup żałuje w nim strat, jakie poniosły dobra Tomasza Zamoyskiego. Cieszy się jednak z ostatecznego zwycięstwa, jakie odniósł hetman Stanisław Koniecpolski nad powracającymi z łupem Tatarami. Zwycięstwo to - jak wiemy - nie było bynajmniej pełne i zgoła nie odpowiadało towarzyszącej mu famie, niemniej stanowiło pocieszenie po nieszczęśliwym najeździe ordy. Marcin Szyszkowski pocieszał też wojewodę kijowskiego, iż klęska Tatarów stanowiła pomstę za wyrządzone wojewodzie szkody. Chwalił zarazem intencję Tomasza Zamoyskiego, iż w tak trudnym czasie nie zaniedbał wyjazdu na zbliżający się sejm ${ }^{49}$. Sam tłumaczył się z nieobecności na sejmie słabym zdrowiem. Narzekał przy tym na postanowienia sejmików, które zabraniały posłom wykraczać poza dane im instrukcje. Biskup słusznie zauważał, że podważa to autorytet sejmu, a także senatorów, którzy tam właśnie mogą działać. Tymczasem krępowanie posłów instrukcjami sejmikowymi czyni z sejmu zakładnika poszczególnych ziem i województw. Niemniej, biskup krakowski wyrażał nadzieję, że wobec grożących zewsząd niebezpieczeństw szlachta zgodzi się na podatki i poszczególni posłowie, nie bacząc na wiążące ich instrukcje, pozwolą na to, na co zgodzą się wszyscy ${ }^{50}$. Było to jak najbardziej

${ }^{48}$ Szwedzi opanowali w Inflantach miasta Dorpat, Rzeżycę i Lucyn, a 8 października $1625 \mathrm{r}$. zdobyli Mitawę, stolicę Kurlandii. Na temat tej kampanii zob. Z. Bruliński, Wyprawa hetmana wielkiego litewskiego Lwa Sapiehy do Inflant w 1625 r., ,Studia historyczno-wojskowe”, 1 (2006), s. 77 92.

${ }^{49}$ Sejm ten obradował w Warszawie od 27 stycznia do 10 marca 1626 r. Na jego temat zob. J. Kwak, Sejm warszawski 1626 roku, Opole 1985.

${ }^{50}$ Warto zauważyć, iż Marcin Szyszkowski był konsekwentny w swych poglądach, dotyczących uprawnień sejmu i zwiększenia efektywności jego działania, gdyż jeszcze jako biskup płocki na sejmie w $1616 \mathrm{r}$. wypowiadał się za ograniczeniem prawa do pojedynczego sprzeciwu, a nawet za wprowadzeniem głosowania większościowego - zob. E. Opaliński, Sejm srebrnego wieku 15871652, Warszawa 2001, s. 234. 
zgodne z obowiązującą praktyką i często same sejmiki, zakazując swym posłom zgadzania się na coś w czasie sejmu, czyniły wyjątek, jeśliby i wszyscy inni na to się zgodzili51. Kończy biskup krakowski swój list życzeniami otrzymania przez Tomasza Zamoyskiego buławy mniejszej koronnej, niewątpliwie wiążąc to z jego zasługami z jesiennej kampanii przeciw Kozakom. Swoje życzenia fundował Marcin Szyszkowski na przekonaniu, iż król nie omieszka wynagrodzić Stanisława Koniecpolskiego buławą wielką po świeżo odniesionym sukcesie nad Tatarami, a wtedy zawakuje urząd hetmana polnego. Jak wiemy, rachuby biskupa krakowskiego okazały się błędne, a Tomasz Zamoyski nigdy nie doczekał się spełnienia wyrażonych w omawianym liście życzeń.

Przedstawiona poniżej korespondencja dowodzi, iż biskup krakowski Marcin Szyszkowski, choć był osobą duchowną i rządził diecezją oddaloną od kresów południowo-wschodnich, nie tylko żywo interesował się sprawami kozackimi i zagrożeniem tatarskim, ale miał w nich całkiem dobrą orientację. Mimo trudności z przekazywaniem listów, wynikających już to z panującej zarazy, już to z zagrożenia przez czambuły tatarskie, potrafił utrzymać kontakt $\mathrm{z}$ wojewodą kijowskim i zdobywać na bieżąco wiadomości o wydarzeniach na kresach. W tonie korespondencji z Tomaszem Zamoyskim można wyczuć wielki szacunek i chęć pozyskania sobie potężnego magnata przez biskupa krakowskiego - było to być może pokłosiem niewielkiego znaczenia rodu Szyszkowskich w porównaniu z Zamoyskimi. Nie przeszkadzało to jednak biskupowi trzeźwo oceniać sytuację polityczną i dawać wojewodzie krakowskiemu dobre rady, tak dotyczące sposobu finansowania rosnących potrzeb Rzeczypospolitej, jak i nadużyć w funkcjonowaniu jej organów parlamentarnych - sejmu i sejmików. Nie bez znaczenia pozostaje też sfera ideologii i postaw najwyższych kręgów społeczeństwa polskiego, do których należeli biskup krakowski i wojewoda kijowski, odnośnie poruszanych w listach spraw wojskowych i politycznych. W dalszej perspektywie wydaje się zatem zasadna edycja i naukowe omówienie większej ilości korespondencji z tego okresu, które pozwoliłyby na przebadanie stosunku hierarchii kościelnej do najważniejszych spraw polityki zagranicznej i wojskowej Rzeczypospolitej, a także tego, co było nervus belli, czyli finansów państwa.

Prezentowane listy wydano $\mathrm{z}$ oryginałów, przechowywanych w wyżej wymienionym zbiorze w Archiwum Głównym Akt Dawnych w Warszawie. Edycję przygotowano w zgodzie z zasadami „Instrukcji wydawniczej dla źródeł historycznych od XVI do połowy XIX w." pod red. K. Lepszego, Wrocław 1953. Starano się zachować brzmienie wyrazów, przy uwspółcześnieniu pisowni. Pozostawiono zatem zapisy „barzo”, „bydź”, „oświatczyć”, „przedtym”, „wszytko” zamiast obecnych „bardzo”, „być”, „oświadczyć”, ,przedtem”, „wszystko”. Ujednolicono pisownię wyrazów, kończących się na -tia, -ia, stosując końcówkę -yja (np. okazyja). Uwspółcześniono pisownię spolszczonych wyrazów pochodzenia łacińskiego, np. affekt - afekt, commissia - komisyja, incursia - inkursyja. Podobnie postąpiono $\mathrm{z}$ nazwami własnymi i tytułami pochodzenia obcego, takimi jak

${ }^{51}$ Posłowie zresztą sami pozwalali sobie często na odstąpienie od instrukcji sejmikowych w imię ratowania zgody powszechnej na sejmie i nie musieli obawiać się z tego tytułu jakichś większych przykrości ze strony swoich wyborców - zob. Opaliński, Sejm srebrnego wieku, s. 159-161. 
Constantinopol (Konstantynopol), Cham (chan), basza (pasza), gałga (kałga). Pojawiające się skróty rozwiązano - np. „Rzpta” - „Rzeczpospolita”. Zachowano jednak skróty, dotyczące tytulatury, stosowane przez Marcina Szyszkowskiego, jedynie je ujednolicając (J.K.M. - Jego Królewska Mość, J.K.Mci - Jego Królewskiej Mości, J.M.P. - Jego Mość Pan, J.M. Pana - Jego Mość Pana, W.M. mój M.P. - Wasza Miłość mój Miłościwy Pan, W.M. mego M. Pana - Waszej Miłości mego Miłościwego Pana, itp.). Uzupełnienia tekstu, pochodzące od wydawcy, umieszczono w nawiasach kwadratowych. Brakujące słowa i archiwalną paginację oryginałów podano kursywą w nawiasach kwadratowych. Edycję opatrzono przypisami rzeczowymi, umieszczonymi tam, gdzie objaśniane przez nie osoba lub sprawa pojawiają się po raz pierwszy. W przypadku niemożności zidentyfikowania osoby, zrezygnowano z podawania tego faktu w przypisie.

\section{Listy Marcina Szyszkowskiego do Tomasza Zamoyskiego}

\section{1}

Marcin Szyszkowski do Tomasza Zamoyskiego, Iłża, 15 IX 1623 r.

AGAD, Zespót 358: Archiwum Zamoyskich, sygn. 384, s. 3-4

Jaśnie Wielmożny a mnie Wielce Miłościwy Panie Wojewodo Kijowski

Już nie śmiem do W.M. mego M. Pana posyłać, bo z trudnością kozak przebydź ma, gdyż na wielu miejscach powietrze panuje, aby zaś abo mnie, albo W.Mci nie zaraził. Do Lublina tylko, iż jeszcze jest jedna droga bezpieczna, ten list mój posyłam, a stamtąd użyłem niektórych, coby go do W.M. mego M. Pana bezpiecznie przesłali i z temi nowinami, które mi posłał starosta mój koziogłowski ${ }^{52}$ o porażeniu lisowczyków naszych. Zda mi się, że ich potym nierychło namówią Niemcy do siebie na służbę, gdy im taką sztukę wyrządzili. Do ośmi set ich pewnie zabito. To też W.M. memu M. Panu oznajmuję, że książę J.M.P. koniuszy ${ }^{53}$ miał z Konstantynopolu od wezyra listy. Beły i do J.K.Mci przy tym i czausza posyła, który przez Siedmigrodzką ziemię jedzie. Upewnia nas o pokoju i od

${ }^{52}$ Aleksander Denisz, zwany Murzynem, zm. po 1633 r. Na jego temat zob. m.in. W. Nekanda Trepka, Liber generationis plebeanorum (,Liber chamorum”), oprac. R. Leszczyński, Wrocław 1995, nr 409, s. 128 i F. Kiryk, J. Rajman, Miasta ziemi siewierskiej, w: Siewierz. Czeladź. Koziegłowy. Studia i materiały z dziejów Siewierza i księstwa siewierskiego, red. F. Kiryk, Katowice 1994, s. 329-330. Koziegłowy - miasto w ówczesnym Księstwie Siewierskim, należącym do biskupów krakowskich; obecnie w powiecie myszkowskim województwa śląskiego, ok. $28 \mathrm{~km}$ na południe od Częstochowy.

${ }^{53}$ Krzysztof Zbaraski (ok. 1580-1627), od 1619 r. koniuszy koronny. W latach 1622-1624 odprawił poselstwo do Turcji, w czasie którego uzyskał potwierdzenie traktatu, zawartego w październiku 1621 r. pod Chocimiem. 
Turków i od chana ${ }^{54}$, a Kantymira ${ }^{55}$ koniecznie znosić kazał; więc nie wiem, jeśli się da, bo potężnie bronić chce Turkom przeprawy przez Dunaj. Nie wiem, jeśli tego dokaże. Trzeba się go nam przecie zawsze obawiać. Piszą z Konstantynopolim, de data 8. Aug[usti], że zaraz po skończeniu Bajranu ${ }^{56}$ dwadzieścia tysięcy ludzi wyprawiono do Węgier Gaboremu $^{57}$ na pomoc przeciw cesarzowi ${ }^{58}$. A drugie wojsko, w którym kilkadziesiąt tysięcy ludzi, przeciwko Abazie paszy ${ }^{59}$ rebelizantowi, który się barzo zmocnił i pod[ob]no będzie prętko ostatnią ruiną państwa tureckiego. Oddaję się [4] przy tym z powolnością służb moich łasce W.M. mego M. Pana. Dan z Iłże, die 15. Septembr[is] 1623.

W.M. mego M. Pana życzliwy przyjaciel i sługa powolny

Marcin Szyszkowski biskup krakowski

\section{2}

Marcin Szyszkowski do Tomasza Zamoyskiego, Bodzentyn, 2 XII 1625 r.

AGAD, Zespót 358: Archiwum Zamoyskich, sygn. 384, s. 10-13

Jaśnie Wielmożny a mnie Wielce Miłościwy Panie Wojewodo Kijowski

Luboś się W.M. mój M.P. odemknął z tych tu krajów bliższych nas, na służbę Rzeczypospolitej i obronę naszę, nie ustawałem jednak ja w mojej ku osobie W.M. mego M. Pana uprzejmej życzliwości, pytając się często o dobrym zdrowiu i szczęśliwym powodzeniu

${ }^{54} \mathrm{~W}$ czerwcu 1623 r. doszło do zmiany na tronie krymskim - miejsce Dżanibeka II Gereja (1610-1623) zajął Mehmed III Gerej (1623-1624, 1624-1628) - zob. Skorupa, Stosunki polsko-tatarskie, s. 251-252 i D. Kołodziejczyk, The Crimean Khanate and Poland-Lithuania: international diplomacy on the European periphery (15th-18th Century). A study of peace treaties followed by annotated documents, Leiden-Boston-Brill 2011, s. 131.

${ }^{55}$ Kantymir (Kantemir, zm. 1637), przywódca ordy nogajskiej, koczującej na Budziaku i nominalnie tylko uznającej zwierzchnictwo Chanatu Krymskiego. W 1620 r. w głównej mierze przyczynił się do klęski wojsk polskich, wracających spod Cecory. Zginął, zamordowany z rozkazu sułtana, po przegranej wojnie domowej z chanem krymskim Inajetem Gerejem.

${ }^{56}$ Bajran - właśc. Bajram, z tur. bayram - święto. W tym przypadku chodzi o tzw. Ramadan Bajram, święto zakończenia postu, obchodzone ostatniego dnia miesiąca ramadan (tur. ramazan). W 1623 r. dzień ten przypadał na 27 lipca (30 ramazan 1032 roku hidżry).

${ }^{57}$ Gabor Bethlen (1580-1629), książę siedmiogrodzki w latach 1613-1629.

${ }^{58}$ Ferdynand II Habsburg (1578-1637), od 1619 r. cesarz rzymski. Był szwagrem króla Zygmunta III Wazy.

${ }^{59}$ Abaza Mehmed pasza (1576-1634), turecki namiestnik Erzurumu. Kiedy w 1623 r. został pozbawiony stanowiska, wzniecił bunt, rzekomo w celu pomszczenia sułtana Osmana II, zamordowanego przez janczarów w 1622 r. Abaza Mehmed pasza nawiązał kontakty z Persją, a w swym pochodzie na Stambuł dotarł aż do Bursy, którą opanował. Nie zdołał jednak zająć stolicy. Pokonany przez wielkiego wezyra Hafiz Ahmeda paszę pod Kayseri w sierpniu 1624 r., uzyskał jednak ułaskawienie i powrót na stanowisko w Erzurumie. W sierpniu 1627 r. zbuntował się ponownie, gdy kazano mu wyruszyć na wojnę z Persją, odmawiając zarazem powierzenia naczelnego dowództwa. Tym razem Abazę Mehmeda paszę pokonał nowy wielki wezyr, Hüsrew pasza, zmuszając w $1628 \mathrm{r}$. zbuntowanego namiestnika do poddania się w Erzuzrumie. Ponownie ułaskawiony, Abaza Mehmed został przeniesiony do Europy, gdzie otrzymał stanowisko bejlerbeja Bośni. W latach 1633-1634 toczył walki z Polską, ale został pokonany. Wtedy to sułtan Murad IV polecił go zgładzić. Zob. Dzieje gospodarcze i spoteczne imperium osmańskiego 1300-1914, red. H. Inalcik, D. Quataert, Kraków 2008, s. 363-365. 
WMci, który jestem tak devotus nomini W.M. mego M. Pana, iż nie życzę więtszej wzajem sobie od W.M. mego M. Pana miłości. Pana Boga tylko proszę, abym to mógł kiedy w jakiej okazjej oświatczyć, żebyś to W.M. widział we mnie, jakom jest życzliwym sługą i przyjacielem W.M. mego M. Pana. Miałem i stąd wielką pociechę, kiedym słyszał o wielkiej ochocie W.Mci ku Rzeczypospolitej, żeś się wezbrał z wielkim pocztem, a rzekę wojskiem, na służbę Ojczyzny do obozu pod regiment J.M. Pana hetmana. Brałem zaraz otuchę wielką, że tam sprawy Rzeczypospolitej miały iść porządnie, że i ta komisyja kozacka miała wziąć pożądany skutek, i gratulowałem J.K.Mci i Rzeczypospolitej, że W.M. mój M.P. takeś się gorąco zapalił do służby Rzeczypospolitej i ratunku Ojczyzny, żeś nie koszt tylko, tak wielki prowadząc pułk, ale trudy wszelakie, na ostatek zdrowie swoje ważył. Za co słuszna, abyś W.M. odniósł wdzięczność wielką od J.K.Mci i Rzeczypospolitej. A mam li prawdę rzec, jako ten, który szczerze rad służę i miłuję W.Mci, obawiając się tego, co jest subsequutum przy tej mojej pociesze, którąm miał z bytności W.Mci w obozie, poniekąd frasowałem, abyś był W.M. o niebezpieczeństwo jakie zdrowia nie przyszedł, jakom to i przedtym W.Mci mówił. Tak wielkim ludziom, którzy bywają ozdobą i podporą Rzeczypospolitej, trzeba się szanować, zwłaszcza kiedy Pan Bóg jeszcze nie dał successorem masculum, a teraz wziąwszy wiadomość o tym, iżeś W.M. w tej z [11] Kozakami potrzebie był w wielkim po dwakroć niebezpieczeństwie, że też i konia pod W.Mcią postrzelono, barzom się zafrasował, i proszę W.M. mego M. Pana, abyś tego in posterum nie czynił. Wielcy ludzie dosyć jest, że wojska posyłają Rzeczypospolitej, a w wojsku zaś rady zdrowej dodają, do potrzeby inszych (gdyż Pan Bóg tak dysponował) Rzeczpospolita ma służebnych. A teraz Pana Boga chwalę, że W.Mci z tego niebezpieczeństwa wyprowadził, którym zaraz tak wiele sławy dobrej przyczynił, że i nieprzyjaciel żaden nie będzie mógł teraz obmurmurare. Pociechy tej mej, którąm wziął z tej sławy W.Mci nieśmiertelnej, nie mogłem w domu zatrzymać, nie zaniechywam i inszym oznajmować, i na sejmiku da Pan Bóg przyszłym przypomnę, aby in facie Rzeczypospolitej podziękowano W.M. memu M. Panu. Ale chciałem też y W.M. memu M. Panu to opowiedzieć i umyślnie posyłam, winszując dobrego na ten nowy rok zdrowia i błogosławieństwa Bożego, spolnie z Jej Mcią Panią wojewodziną moją M. Panią ${ }^{60}$, i zacnym potomstwem W.Mci, życząc, aby Pan Bóg na wiele lat następujących dał we wszystkich sprawach i zamysłach pożądany skutek, jakobyś i radą i pomocą wspierał Rzeczpospolitą, ku chwale Bożej, ozdobie Ojczyzny, nieśmiertelnej sławie swej. Zalecając iterum atque iterum służby moje uprzejme i powolne w łaskę W.M. mego M. Pana. Z Bodzentyna ${ }^{61}$, die 2. Decembr[is] 1625.

W.M. mego M. Pana życzliwy przyjaciel i sługa powolny

Marcin Szyszkowski biskup krakowski

[13] P.S.:

Rozumiem, żeście W.Mciowie to opatrzyli dobrze, żeby te kondycyje od Kozaków poprzysiężone, były in effectum przywiedzione, położywszy tam wojsko J.K.Mci, jeśli nie obozem, przynajmniej wielkimi pułkami, po miastach ich, bo dotąd nie wiemy, jako jest wojsko rozprawione. A iż obawiać się trzeba, aby te hydry za okazyją zaś głów swych nie podnosili, potrzeba nam będzie na przyszłym sejmie znowu obmyślić wojsko, które by tam w Ukrainie między Kozakami było położone, aby do końca mogli bydź wprawieni w posłuszeństwo i zahamowani od inkursyj morskich do Turek, czym byśmy sobie pew-

${ }^{60}$ Katarzyna z Ostrogskich Zamoyska (1602-1642), od 1620 r. żona Tomasza Zamoyskiego.

${ }^{61}$ Bodzentyn, miasto w powiecie kieleckim województwa świętokrzyskiego, ok. $30 \mathrm{~km}$ na północny wschód od Kielc. Od średniowiecza aż do upadku Rzeczypospolitej Bodzentyn należał do biskupów krakowskich, którzy mieli tu własny zamek, przebudowany w XVI w. na rezydencję pałacową. 
niejszy pokój od pogaństwa zjednać mogli. Będzie podobno ciężko dać siła poborów, bo trzeba do Szwecjej i do Inflant i na Ukrainę, lec[z] i z tych po powietrzu przez cztery lata po wszytkiej Koronie panującym mała będzie pociecha, dlatego przyjdzie nam do inszych media uciec się, a od cudzoziemców brać je. Czemu byśmy nie mieli pozwalać Gabellas od wszytkich rzeczy, które przedajemy i kupujemy, tak szlachta jako i mieszczanie, kupcy, i poddani naszy, chociażby dając po półgroszku od złotego, bez ciężaru naszego wielkiego i poddanych mogłoby to bydź. Daję to pod wysoki rozsądek W.M. mego M. Pana, jakoby się zdało, abyś to na sejmikach swych, albo potym na sejmie proponować raczył. Będą podobno zastawiać się wolnościami, ale nie wiem, jeśli to wolności, kiedy Tatarzyn będzie wiązał, et servi nostro dominabuntur nobis, czego Boże racz zachować.

\section{3}

Marcin Szyszkowski do Tomasza Zamoyskiego, Bodzentyn, 4 III 1626 r.

AGAD, Zespót 358: Archiwum Zamoyskich, sygn. 384, s. 14-17

Jaśnie Wielmożny a mnie Wielce Miłościwy Panie Wojewodo Kijowski

Żałuję tego barzo, że pisanie moje nierychło doszło rąk W.M. mego M. Pana, z którym umyślniem ja był posłał Kozaka mego, nie mogąc w sobie długo zatrzymać tej mej pociechy, którąm miał z szczęśliwej rozprawy z Kozakami, której W.M.M.M.P. maxima pars fuit, ażbym był ją i W.M. memu M. Panu, którego mam między wielkimi przyjaciółmi mymi najwiętszego i najmilszego oświatczył i opowiedział. Nieostrożnością się to stało służki mego, który chcąc się prętko nazad wrócić, list mój w Tarnopolu porzucił ${ }^{62}$, a sam bieżał do J.M. Pana hetmana. Za co lubo odniósł swoję naganę, nie stało jednak za moje, że nierychło doszedł ręku W.M. mego M. Pana, ale że i o to ode mnie mile i wdzięcznie przyjmować raczysz, cieszę się z tego, a tym barziej, że uznawam więtszą ochotę i gorętszy afekt do służby Rzeczypospolitej. Za co niechaj Pan Bóg W.Mci błogosławi, i w dobrym zdrowiu i wszelakich zamysłach pomnaża. O co go ja niegodny proszę. Ja mam to sobie za wielką pociechę, gdy często słyszę o dobrym zdrowiu W.M. mego M. Pana, i dlatego często się pytywam o nim i gdyby mi to dał Pan Bóg, żebym gdzie bliżej mieszkał W.Mci, nie przez listy, ale obecnie ${ }^{63}$ często byśmy cieszyli się z sobą. Teraz za tymi niebezpieczeństwy, któremi Pan Bóg Ojczyznę tę naszę z łaski swej nawiedza, i listów przesyłać niebezpieczno, za czym mię też bywa tęskno, że się nie znoszę z W.M. mym M. Panem. Afekt mój jednak taki jest przeciwko W.M. memu M. Panu, jakobyśmy ustawicznie z sobą przebywali. Jeśli locorum intervalla nas łączą, ale animorum coniunctio integra zostaje. Pana Boga tylko proszę, aby mi jeszcze raczył użyczyć zdrowia tak wiele, żebyś mógł patrzyć na ten afekt mój, z którego życzę W.M. memu M. Panu maxima quoque ornamenta et incrementa [15] fortunarum w Rzeczypospolitej i wszytkiego, co jedno po łasce Bożej może cadere in desiderium W.M. mego M. Pana, jako to ex his qualitatibus, którymi Pan Bóg W.Mci obdarzył optimo iure debetur. I dla tegoż życzyłem sobie barzo, abym był sejmu tego nie pomieszkiwał, żebym był explere mógł desiderium meum, które mam do usługi W.M. mego M. Pana, ale już osłabiałe za laty memi zdrowie, któremu teraźniejsze constitutiones aeris barzo szkodzą, tak że z izby wychodzić najmniej nie pozwolą, a jeszcze by nie żal i zdrowia odważyć, gdyby się co sprawić mogło, do słabości mej niemniej są mi przyczyną były pozostania w domu praeiudicatae conclusiones sejmi-

${ }^{62} \mathrm{Z}$ uwagi na grasującą w Polsce zarazę, Tomasz Zamoyski już w 1625 r. przebywał z rodziną w Tarnopolu - zob. Żurkowski, Żywot Tomasza Zamoyskiego, s. 96.

${ }^{63}$ osobiście 
ków, na których że nie kazano posłom nic postępować nad opisanie Artykułów sub poena colli, czego nigdy przedtym nie bywało, i że do tego przychodzi, żal się Boże. Bo cóż my, senatorowie, sprawić możemy i po co na sejmy jeździć mamy, kiedy na sejmikach sejmy zawierają. Nie wątpię, że i to W.M. memu M. Panu podobać się nie będzie. Że jednak raczysz jechać na sejm, i to pochwalam W.M. memu M. Panu, mając nadzieję, że za tą inkursyją tatarską, za którą tak wielkie szkody odniosła Rzeczpospolita, zechcą się skłonić pp. posłowie do takich subsidia pozwolenia, za którymi by ze wszech stron Rzeczpospolita była opatrzona od niebezpieczeństw onę zachodzących, i lubo nie mogą nic nad Artykuły pozwolić. Mogą jednak wziąć do braciej, którym po sejmie J.K.M. złoży sejmiki, bez pochyby pozwolą wszyscy, kiedy obaczą zgodę wszytkich województw. Cladem istam, którąś wziął od tego poganina, barzo żałuję. Nagrodzi ją Pan Bóg W.M. memu M. Panu za ten gorący afekt, który masz do służby Rzeczypospolitej. A nie wątpię, że i za tą wiktorią szczęśliwą, którą odniósł J.M.P. hetman z tego pogaństwa tuż się poniekąd koi serce W. Mci, że inultus [wróg] nie odszedł. Tak się spodziewam, że tak częstymi a szczęśliwemi zwycięstwy J.M. Pana hetmana koronnego, zechce Król J.M. wielkim hetmaństwem J.M. [hetmana polnego] kondekorować, a [16] za tym W.M. mego M. Pana polnym, czego ja uprzejmie życzę i jako przedtym, tak i teraz będę radził to J.K.Mci, abyś zasług swych odniósł condigna praemia. Zalecam przy tym powolne służby moje łasce W.M. mego M. Pana. Z Bodzentyna, die 4 Martii 1626.

W.M. mego M. Pana z dawna życzliwy przyjaciel i sługa powolny

Marcin Szyszkowski biskup krakowski

\title{
MARCIN SZYSZKOWSKI'S LETTERS TO TOMASZ ZAMOYSKI - COSSACK AND TARTAR-AND-TURKISH CASES (1623-1626)
}

\begin{abstract}
Summary
The first half of twenty years of 17 th Century is a period of gradual normalization of Polish and Turkish relations after the Great War of 1620-1621. Challenging the issue of Zaporowscy Cossacks and their looting expeditions in the Black Sea effectively was regarded as the pre-condition of success for this normalization process. The Republic of Poland tried to achieve both targets by means of the mission of Priest Krzysztof Zbaraski to Stambul in the years of 1622-1623, and the commission, as well as the subsequent military encounter with the Cossacks in 1625. Members of political elites were also sometimes directly involved in achieving those targets. This article presents three letters from Cracow Bishop Marcin Szyszkowski to the Governor of Kiev Tomasz Zamoyski. The letters being kept in custody of Zamoyski Archive affiliated to the Central State Historical Archives in Warsaw. Those letters were written in the years of 1623-1626 and referred to political issues. Apart from the factual content, they allow to learn about the attitude of Senator Marcin Szyszkowski, being the clergyman, to the said political and military events. They also expose personal relations between magnates and politicians. Therefore the letters incorporate themselves into the research on military and political history as well as the philosophy of life and the position of people of the Church as far as public life is concerned in the Republic of Poland of 17th Century.
\end{abstract}

